\title{
The changing role of migration and natural increase in suburban population growth: The case of a non-capital post-socialist city (The Krakow Metropolitan Area, Poland)
}

\author{
Sławomir KUREK ${ }^{\text {a***, }}$, Mirosław WÓJTOWICZ ${ }^{\text {a }}$, Jadwiga GAŁKA ${ }^{\text {b }}$
}

\begin{abstract}
The evolution of population distributions in the Krakow Metropolitan Area (KMA) in Poland is subject to analysis in this contribution. Changes and recent reversals in the relationships between the main components of total population growth (natural increase and net migration) are examined in order to determine the level of development of suburbanisation processes in zones of the KMA, with the use of the Webb typology. Research was carried out in four time points: 1988, 1995, 2002 and 2012, covering the year just before the collapse of the socialist regime, the first decade of political and socio-economic transition, and the period before and after accession to the EU. The analysis of differentials in natural increase and net migration is conducted within the context of residential suburbanisation in the KMA, using as a background context recent population developments in Poland and Polish cities. Implications for urban policy arising from changes in the spatial concentration of the population in the metropolitan area are discussed.
\end{abstract}

Keywords: suburbanisation; metropolitan areas; population change; natural increase; migration; Krakow; Poland

\section{Introduction}

Urbanisation is a spatial process where, in an early phase, the geographical distribution of population gradually concentrates in cities, while at a later stage urban lifestyles and infrastructure diffuse to the countryside. According to van den Berg et al. (1982), the process of movement of the population from city centres to peripheral areas is the phase of urban development known as suburbanisation, which results from the depopulation of core cities (Klasseen et al., 1981; Champion, 2001). On the other hand and especially in the cities of Western Europe, a renewed process of population concentration is observed, which is the result of processes of gentrification and urban policy measures aiming to revitalize town centers through the development of housing on brownfields, to increase the level of education of the population, as well as the effects of the second demographic transition (Buzar et al, 2007; Haase et al., 2010; Rae, 2013; Steinführer and Haase, 2007; van de Kaa, 1987). Therefore, current pictures of urban development in western Europe are more diversified - between core cities and fringe areas, owing to both the coexistence of suburbanisation and developing reurbanisation (Kabisch and Haase, 2011; Rérat, 2012), which is opposite to the sequential model that van den Berg et al. originally proposed.

For post-socialist cities in the late twentieth and early twenty-first century, however, many researchers report that suburbanisation is one of the major processes shaping spatial development and population dynamics (Hirt, 2007; Leetmaa and Tammaru, 2007; Leetmaa et al., 2009; Ouŕedníček, 2007). Such trends are manifested by an increase in population numbers in the hinterland of larger towns, which is caused by the transition from a centrally planned to a market economy, and by the emergence of a real estate market. Population growth in suburban areas thus can be the result of increased in-migration - but other components (especially, natural increase) should also be taken into account. On the one hand, fertility declining to low values far below replacement levels, has been observed along with the diffusion of the 'second demographic transition' (van de Kaa, 2003; Sobotka, 2008; Lesthaeghe, 2010). On the other hand, residential mobility may encourage couples to have more children (Vobecka and Piguet, 2012), as it is generally recognised that suburban areas record higher fertility levels than urban centres and differences in fertility by residential context persist even when controlled for the effect of population composition and selective migrations (Kulu and Washbrook, 2014).

This article aims to analyse changes in the spatial concentration of population, using the case of the Krakow Metropolitan Area (KMA) in Poland, in a residential (urban-suburban) context. The research contributes to the existing literature on suburbanisation by focusing on the relationships between the main components of total population growth (natural growth rate and net migration) in the residential zones of a metropolitan area. The following questions are central to our research: How does the development of suburbanisation reflect the influence of the contribution of natural growth and migration in population change, and how are these two components linked? We assume that after an initial increase, the net migration rates exceed natural growth as the main driver of population change. The reversed trend in natural growth, however, in recent years is observed in particular due to a rise in the number of births and selective residential migration of a predominantly young population.

\footnotetext{
${ }^{a}$ Department of Socioeconomic Geography, Institute of Geography, Pedagogical University of Cracow, Poland (*corresponding author: S. Kurek, email: sgkurek@up.krakow.pl)

b Department of Geography of Population, Settlement and Farming, Institute of Geography and Spatial Management, Jagiellonian University in Kraków, Poland
} 


\section{Literature review: Urbanisation development in socialist and post-socialist cities}

The urbanisation process in socialist and capitalist cities was different in that in the former a development priority was the industrialisation of the socialist economy. Socialist urbanisation was characterised by state ownership of urban land and infrastructure and central planning of urban development, while western urbanisation was led by market competition, private property, and realestate profitability, as well as local decision-making (Enyedi, 1992, 1996, 1998).

Urbanisation in socialist cities - characterised by collective ownership, the centrally planned allocation of development funds and centralised decision making has been described as less advanced compared to that in Western Europe. So, when western countries in the 1970s recorded population relocation towards non-metropolitan areas, Eastern Europe recorded rapid growth of industrial employment in cities and high volumes of rural-urban migration. The most important priority of socialist governments was the industrialization of the economy and the growth of industrial cities, both of which were accompanied by the collectivisation of agricultural land and increased waves of rural migrants. As a result, the socialist CEE countries experienced accelerated urbanization rates, which almost doubled between 1950 and 1990 (Stanilov and Sýkora, 2014).

The on-going process of urban development in socialist countries was termed under-urbanisation, where the growth of job opportunities in industry was much faster than the growth of the permanent urban population, due to housing shortages which resulted in massive rural-urban commuting (Murray and Szelenyi, 1984; Szelenyi, 1996). The spatial allocations of public investments in socialist cities were associated with the expansion of industrial zones, development of massive housing estates at the urban edges, as well as the redevelopment of city centres as communist monuments with political and economic motives (Stanilov and Sýkora, 2014). The new multi-family socialist housing estates were located within the administrative boundaries of the cities and were integrated functionally with industrial hubs through mass public transport.

Under these circumstances, socialist urban areas were rather compact, with limited growth of peripheral settlements designated for recreational use (dacha zones) or to the concentration of industrial workers in rural areas due to the restrictions of in-migration to large cities where housing provision usually lagged behind demand (Leetmaa and Tammaru, 2007; Lisowski et al., 2014). Thus, socialist cities were characterised by a centralized system of control over territories developed without suburban communities, in contrast to their western counterparts where suburban units grew as (relatively) politically independent units.

The change from socialist to post-socialist development of urban areas can be referred to as a concept of heteropolitanization (Gentile, Tammaru, van Kempen, 2012). During the socialist era, urban planning was characterised by homogenization and standardisation of housing construction and the administrative allocation of living space. After the collapse in 1989, urban areas experienced several fundamental changes that led to a sociospatial complexity, which distinguished the post-industrial metropolis of the $21^{\text {st }}$ century from its industrial predecessor. These changes were the result of a mix of legacy effects and path dependencies on the one hand, and transition-induced factors associated with globalisation - increased creativity, connectivity and competitiveness, on the other.

The huge demand for urban housing inherited from decades of the socialist regime pushed households away from inner cities to suburban hinterlands, in search of 'friendly' living environments. The main driving forces of suburbanisation in CEE countries were the forces of globalisation and the integration of their states into the global financial and economic networks that were accompanied by the arrival of foreign capital into the real estate sector. Suburban areas gained increasing shares of metropolitan population growth in the form of low-density, developer-built residential environments that were pushed by the rise of a new middle class and supported through the establishment of a system of mortgage financing, as well as large-scale commercial developments altering the post-socialist landscape of metropolitan areas (Stanilov and Sýkora, 2014). It is argued that suburbanisation in CEE countries added specific features to the process, in comparison with the experience of Western countries features that were specifically associated with different dimensions of socio-economic transition, namely privatisation of the housing stock, changes in the labour market, as well as the changing social stratification order (Ladanyi and Szelenyi, 1998).

Massive suburban explosion, however, has been uncontrolled and associated with extensive spatial expansion of built-up areas outside city cores, spreading not only housing but also retail, offices and industrial uses -- in highly fragmented and diffused patterns. These processes lead to urban sprawl and pose major challenges to natural habitat and social cohesion. The dispersal of new housing has strained the ability of the public sector to provide infrastructure and services, has increased car dependency and thus undermined the prospects of sustainable development (Stanilov and Sýkora, 2014: 18-19).

According to Sýkora and Bouzarovski (2012), postsocialist urban restructuring reflects the interactions between three aspects of the 'post-communist' transition: the institutional transformations, the socio-economic, and the cultural transformations exhibited in the everyday life of people, as well as the transformation of dynamics of urban change leading to suburbanisation. Leetmaa et al. (2009) have indicated that suburbanisation in postcommunist countries is different in comparison with "western" suburbanization in that the former has a different socio-economic background, and inherited the spatial context of the multi-family housing market. They also noticed that the transition from priority-led to marketled suburbanisation was gradual and was connected with the changing role of metropolitan actors (households, public authorities and companies). Rebernik (2005) has also pointed out that the processes of suburbanisation in postcommunist cities have been influenced by several specific factors connected to the political and economic transition and its social effects. Researchers have investigated the motivations of movements to new household settlements (e.g. Kährik, Leetmaa, Tammaru (2011), the socio-spatial segregation of suburbanising areas (Marcińczak et al., 2012; Hirt, 2007; Sýkora, 2009, Brader et al., 2009) and the social relationships within new suburban localities (Špacková and Ouředníček, 2012). Few studies, however, have focused on the spatial patterns of suburbanisation (Timár and Varádi, 2011), and the territorial relation between the major 
components of population change in suburban areas, namely natural increase and migration (Vobecka and Piguet, 2012; Kabisch et al., 2012).

It is generally recognized that demographic changes in metropolitan areas in Europe are associated with fertility decline and migration, the latter being an increasingly dominant population growth factor. There were significant changes in population development, however, between western and central-eastern Europe. The former has been characterised by fertility decline since the $1960 \mathrm{~s}$ and an increase of residential migration to the suburban hinterland. In the latter East European case, the process of rural-urban in-migration to the city cores prevailed and was accompanied by relatively high fertility (Kabisch, Haase, Haase, 2012). After 1989, the urban core areas were first affected by population decline resulting from a dramatic decline in natural increase, as well as a decrease in the volume of in-migration. At present, many city cores are characterised by negative population change with negative net migration (outflows of population to suburban areas) and negative natural increase. All of these changes may be associated with the 'second demographic transition' (SDT) (van de Kaa, 1987; Bongaarts, 2002; Lesthaeghe and Meekers, 1986; Lesthaeghe, 2010),) which was first identified in Western Europe in the 1960s and then diffused to CEE countries in the 1990 s. The main features of SDT incorporate fertility decline below replacement levels, an increase in the mean age of mothers at birth, a decline in the number of marriages and an increase in the number of divorces. The decline in fertility is the result of changing attitudes towards having children and, more generally, towards the family, associated with the destabilisation of traditional family structures, including postponement of childbearing and increased diversification of households (e.g. the rise of childless couples).

Considering population changes within metropolitan areas, many studies have been devoted to the role of migration (e.g. Sýkora and Čermák, 1998; Ott, 2001), with special focus on changing migration patterns under the transition process, or to the composition and destinations of suburbanisers (Leetmaa and Tammaru, 2007; Ouředníček, 2007; Stanilov, 2007; Sýkora, 1999; Tammaru, 2001, 2005). In turn, Steinführer et al. (2010) refer to SDT as a concept explaining depopulation in post-socialist cities, leading to a low fertility and reported surpluses of deaths.

\section{The case of Polish cities}

For many years, Polish cities were the main locations for people to settle. Initiated after the Second World War, intensive urbanisation processes and largescale industrialisation processes stimulated migration movements of the population. By the end of the 1980s, migration from rural to urban areas prevailed in relation to the processes of industrialisation and the development of multi-family housing (apartment blocks). After 1989 and the introduction of the principles of a free market economy, there was a change in the direction and intensity of migration flows (Zborowski and Raźniak, 2013). After 1990, the restructuring of industry and the emergence of market mechanisms in the sphere of economy, land and housing, gave rise to migration from cities to rural areas, especially those in the vicinity of urban centres, moulding the social-spatial structure of the population (Parysek and Wdowicka, 2002; Szymańska and Matczak, 2002; Marcińczak, 2012).
The restructuring of the economy and related changes in the labour market, increasing self-awareness of residents, the availability of housing loans and greater freedom in the choice of place of residence, effectively meant that people began to leave the city. Major changes have taken place, especially in metropolitan areas that entered the phase of suburbanisation: these changes were evident in the accelerated migration to the suburban periphery as a principal component of population change (Parysek and Wdowicka, 2002; Szymańska and Matczak, 2002; JakóbczykGryszkiewicz, 1998, 2011; Śleszyński, 2006; Beim, 2010; Lisowski, 2010). Such changes resulted in a negative migration balance in core cities and in a positive migration balance in suburban areas. The outflow of young people from core cities, together with low birth rates, initiated adverse changes in the demographic structure of core cities in Polish metropolitan areas (Warych-Juras and Gałka, 2011).

There has been a rapid development of single-family housing in Poland, which was driven by an increase in personal wealth, lower prices of land and real estate in suburban areas, and the increased availability of mortgage loans. The development of urbanisation also contributed to several social mechanisms, such as the increased environmental awareness of residents, the poor quality of urban housing, an increased demand for higher quality housing to guarantee tranquillity, and a better living environment with respect to 'fashionable rusticity' (Kajdanek, 2011, 2012).

\section{Methodology}

The method used for the study of changes in the main components of population growth was the typology developed by Webb, useful in measuring both static and dynamic views (Długosz, 2001). In its classic application, the typology allows for the identification of relationships between natural increase and net migration in a given year, as well as the spatial variability in the demographic situation (Webb, 1963). Webb distinguished eight types of population change:

- Type A - positive natural increase surpasses negative net migration;

- Type B - positive natural increase surpasses positive net migration;

- Type $\mathrm{C}$ - positive natural increase is lower than positive net migration;

- Type D-positive net migration with surplus compensates negative natural increase;

- Type E-negative natural increase is not compensated by positive net migration;

- Type F - negative natural increase with negative, but not lesser (in absolute value) net migration;

- Type $\mathrm{G}$ - negative natural increase with negative, but not bigger (in absolute value) net migration;

- Type $\mathrm{H}$ - negative net migration is not compensated by positive natural increase.

To analyse the trends, a dynamic approach was used, based on the changes in Webb's categories: (Długosz, 2001; Wiśniewski, 2014), and examining specific time periods. In the present case, they were determined by referring to the main phases of socio-economic transformation that were identified on the basis of changes in macroeconomic and demographic indicators. Due to the fact that with eight types and the theoretical number of combinations being 64 , in order to facilitate the analysis, the typological transition matrix was divided into four major types (Dlugosz, 2001; see Tab. 1): 
- I. permanent populating, when in both sections there is population growth (unit type A, B, C or D which maintains the type designation of this system);

- II. populating, when population decline in the first period is stopped and, in the second period, the population grows (unit of type E, F, G or $\mathrm{H}$ changes into type A, B, C or D);

- III. depopulating, when population growth in the first period is stopped and, in the second period, the population declines (unit of type A, B, C or D changes into type $\mathrm{E}, \mathrm{F}, \mathrm{G}$ or $\mathrm{H}$ ); and

- IV. permanent depopulating, when in both sections there is population decline (unit type $\mathrm{E}, \mathrm{F}, \mathrm{G}$ or $\mathrm{H}$ keeps the type designation of this system)

\begin{tabular}{|c|c|c|c|c|c|c|c|c|}
\hline Type & A & B & C & D & E & F & G & H \\
\hline A & I & I & I & I & III & III & III & III \\
\hline B & I & I & I & I & III & III & III & III \\
\hline C & I & I & I & I & III & III & III & III \\
\hline D & I & I & I & I & III & III & III & III \\
\hline E & II & II & II & II & IV & IV & IV & IV \\
\hline F & II & II & II & II & IV & IV & IV & IV \\
\hline G & II & II & II & II & IV & IV & IV & IV \\
\hline H & II & II & II & II & IV & IV & IV & IV \\
\hline
\end{tabular}

Tab. 1: Scheme of theoretical connections for four dynamic types (the first period in the rows). Source: Dtugosz, 2001: 64

For a more detailed analysis, sub-types can be used. They show the changing relations between the components of total population growth (Tab. 2):

- 0 - stabilised, when the relationship between the components of the Webb system remains unchanged;

- $\mathrm{x}$ - reversed, when the relationship between the components of the Webb system changed radically;

- a - increasing natural increase, when the relationship between the components of the Webb system are changing due to the increasing role of natural increase;

- b - increasing net migration, when the relationship between the components of the Webb system are changing due to the increasing role of net migration;

- c - declining natural increase, changing due to the decreasing role of natural increase;

- $\mathrm{d}$ - declining net migration, when the relationships between the components of the Webb system are changing due to the decreasing role of net migration.

\begin{tabular}{|c|c|c|c|c|c|c|c|c|}
\hline Type & A & B & C & D & E & F & G & H \\
\hline A & o & b & b & b & X & C & c & d \\
\hline B & a & o & b & b & C & X & d & d \\
\hline C & a & a & o & b & C & C & x & d \\
\hline D & a & a & a & o & C & D & d & x \\
\hline E & x & a & a & b & O & D & d & d \\
\hline F & a & x & b & b & C & O & d & d \\
\hline G & a & a & x & b & C & C & o & d \\
\hline H & a & b & b & x & C & C & c & o \\
\hline
\end{tabular}

Tab. 2: The scheme of theoretical connections within 8 types (the first period in rows). Source: Dtugosz. 2001: 65
The research reported here was carried out for the municipalities in four time periods: 1988, 1995, 2002 and 2012. The averages for demographic indicators, however, were calculated from three-year-periods (1987-1989, 19941996, 2001-2003 and 2011-2013 respectively). The first study period covers the situation before the socio-economic transition; the second summarizes the first stage of transformation; while the next time periods span the years before and after joining the European Union. In the final part of this report, the implications for urban policy arising from changes in the spatial concentration of the population in the metropolitan area, are discussed.

The analysis included data on vital and migration statistics from the population registration derived from the Central Statistical Office (Regional Databank). Some populations fail to register their permanent residency shortly after moving into a new place, however, which could affect the final results and underestimate the actual size of migration flows and postponing them in time.

According to Śleszyński (2011), the population numbers in suburban areas may be underestimated by 10 percent. An incomplete registration of migration also makes it impossible to assess the accurate volume of births and deaths, because fertility and mortality statistics are based on the permanent address register (Steinführer et al., 2011). Furthermore, it should be noted that the data produced by the central statistical office are published with a rural-urban division, not taking into account the so-called Standard Metropolitan Statistical Areas, as metropolitan areas are not defined in official statistics. They appear only in land-use planning or scientific analysis. These difficulties notwithstanding, we have attempted to investigate the level of demographic changes in the research area, being aware that the data used are the only available, long-term and complete statistical materials.

\section{The study area}

The study was conducted for the Krakow Metropolitan Area (KMA), a functional region, which includes the city, Krakow, and the surrounding group of 50 municipalities in eight districts (poviats), including one urban municipality, 14 urban-rural municipalities (consisting of a town together with its surrounding villages and countryside), and 35 rural municipalities. Taking into account the classification of urban and rural units and including Krakow, the KMA encompasses 65 spatial units, which were included in this analysis (Fig. 1). The Krakow Metropolitan Area and its division into suburban and commuting zones were established on the basis of commuting patterns to Krakow, in which at least $30 \%$ of the working population commute to the central city (Zborowski, 2005; Zborowski et al., 2010). In 2012, the KMA region had a population of 1,488 thousand people, of which 759 thousand resided in Krakow (51 per cent of the entire metropolitan region). It should be noted that the share of the population of Krakow in the total KMA population is decreasing (in 1988 it amounted to 54.2 per cent). In terms of demographic potential, the metropolitan area of Krakow occupies $3^{\text {rd }}$ place in Poland, after the Upper Silesian and Warsaw metropolitan areas.

\section{Population dynamics}

After 1989, the socio-economic transition in Poland was associated with an increase in unemployment and a decline in fertility and the volume of migration. The natural increase 


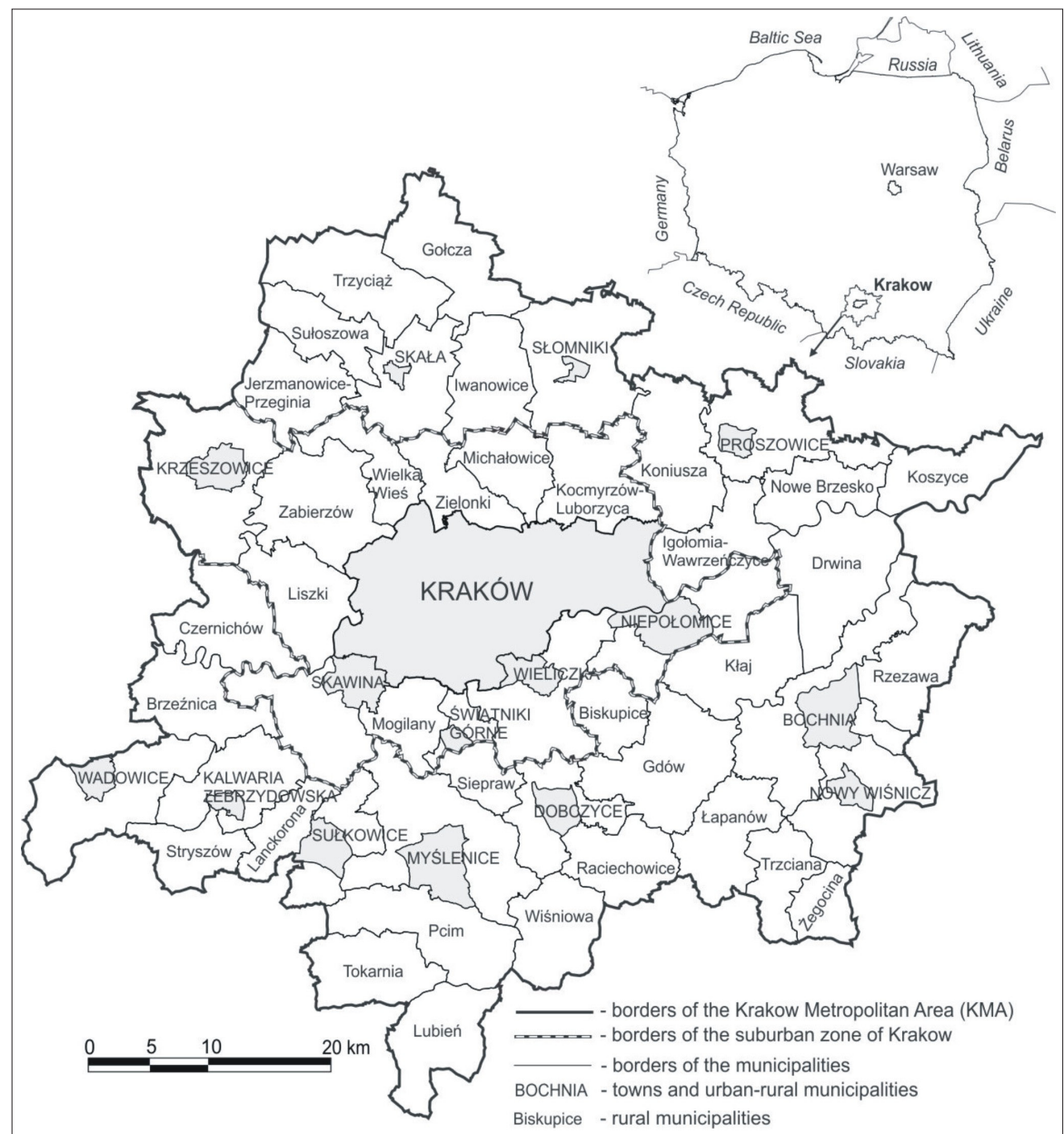

Fig. 1: Territorial extension of Krakow Metropolitan Area (KMA)

in Poland decreased from 5.7 to 0.0 per thousand population from 1988-1999. Also, there was a decline in the volume of domestic migration: flows recorded a considerable drop from 639.5 thousand in 1988 to 369.3 thousand in 2001. In spatial terms, the main trends in population distribution were the concentration of population in metropolitan areas, a deconcentration within metropolitan areas leading to suburbanisation, as well as the depopulation of peripheral rural areas (Węcławowicz et al., 2006).

In the years from 1988 to 2012, the population of the Krakow Metropolitan Area increased by 8.1 per cent: the highest average annual growth was recorded in the last studied period, 2002-2012. This sharp population growth in urban and suburban areas was masked by a long-term spatial differentiation (Fig. 3), with suburban areas outperforming by far the core city with respect to absolute population growth. In Krakow, from 1988-2012, the population increased slightly from 746,000 to 759,000 (according to the Central Statistical Office data), while the population in the remaining KMA area increased from 630,600 to 729,000 (by $15.6 \%$ ), and in its suburban zone from 218,100 to 273,100 (by $25.2 \%$ ). In spatial terms, in the period from 1988 to 1995,10 study units out of 65 , including Krakow, recorded a decline of population; the declines occurred mainly in units in the northern part of the KMA. The largest population growth occurred municipalities located in the southern part of the KMA (with an increase of more than 10 per cent). In the second analysed period (1995-2002), 49 municipalities exhibited population growth with the largest increase in units with convenient locations and proximity to the centre of Krakow (up to 22 per cent), where housing was already in intensive development, effectively accelerating residential suburbanisation (Zborowski, Chaberko, Kretowicz, 2011; Wiecław-Michniewska, 2011). The largest decrease occurred in agricultural municipalities located in the northern part of the study area (over $6 \%$ ).

In the last examined period, 2002-2012, population decline was noted only in seven (7) units, while an increase in the number of residents moving to the outskirts of Krakow became even more pronounced, reaching up to 35 per cent. According to the available data, Krakow in different subperiods as well as in the complete research period, was characterised by small fluctuations in population.

A synthetic picture of the spatial dynamics of the population in the years 1988-2012 shows clearly the diversity of the Krakow Metropolitan Area (Fig. 2):

- the northern part, with mostly agricultural land use and an ageing population structure, shows negative total population growth;

- the zone of cities and municipalities in the immediate vicinity of Krakow is characterised by a significant increase in population, except for areas located east of the Nowa Huta district (agricultural land use and proximity to the steelworks); and

- the southern part with high population dynamics, especially along the main road towards the Zakopane resort.

Thus the diversification in the dynamics of population change in KMA was the result of the economic functions performed, proximity to Krakow and its accessibility, as well as attractiveness for investment purposes. 


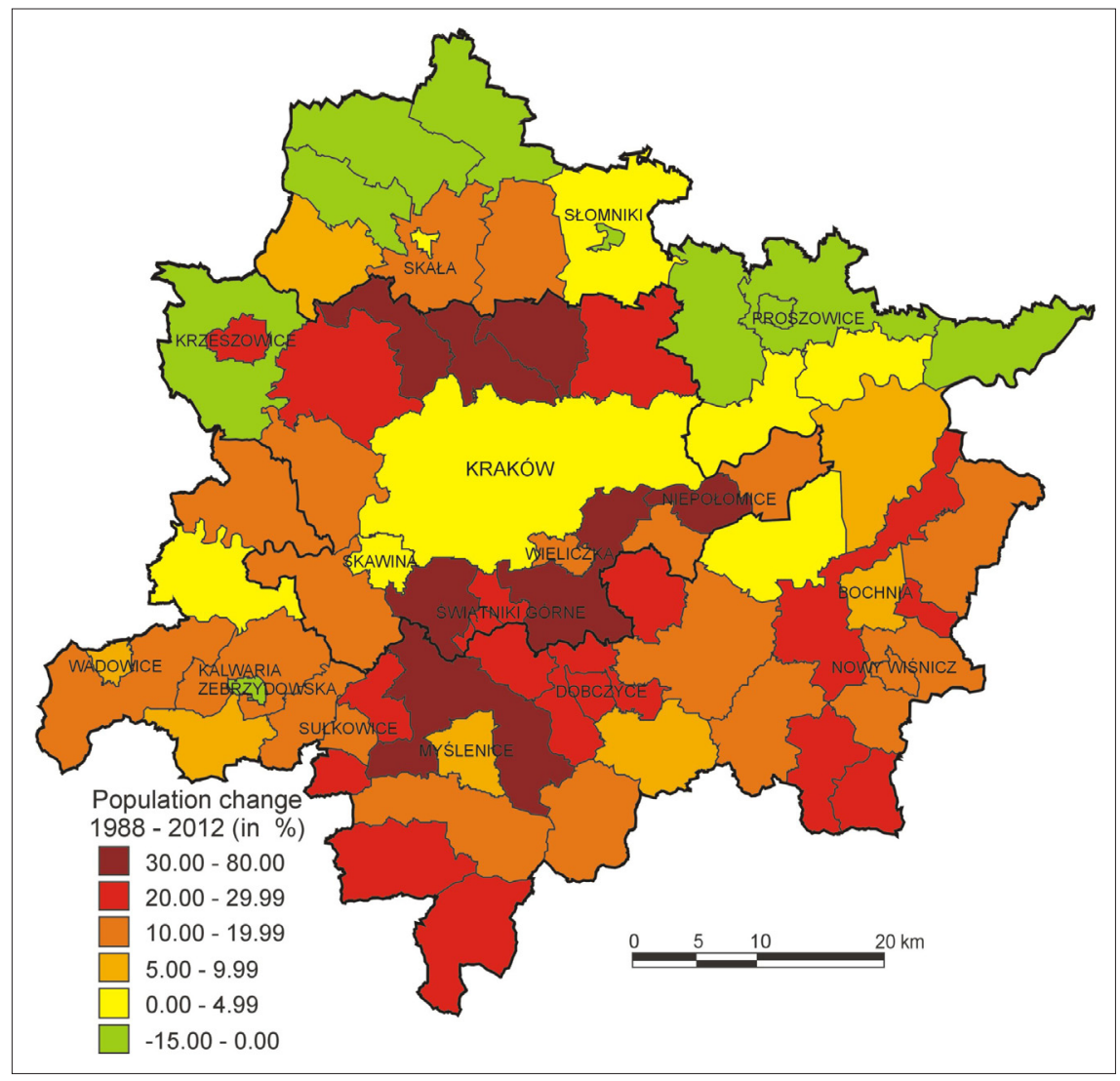

Fig. 2: Spatial patterns of population change in Krakow Metropolitan Area in 1988-2012

\section{Webb typology (static)}

In this section we seek to answer the following questions: Which of the components of total population growth (natural increase or net migration) was dominant? ... and, if the relationship between these components changed in certain periods? We used the Webb typology for both the static and the dynamic approaches. Taking into account all urban areas in Poland, at the turn of 1980s and 1990s, they are represented as type $\mathrm{C}$, with positive net migration offsetting natural increase (Fig. 4). It was not until 1998, however, that the negative migration balance grew in importance in urban areas (within their administrative borders) and they began to show Webb's type G - where negative net migration surpassed negative natural increase. In recent years, Polish urban areas have moved towards type $\mathrm{H}$, recording positive natural increase which, however, did not compensate for any negative migration balance. In the last two years, the natural increase in Polish cities reached negative values again, so they moved to type $\mathrm{G}$.

In 1988, type A was the most common among the surveyed units (39 out of 65). In this type, the loss of population caused by net migration was more than compensated for by natural increase (Fig. 4a). This type included units located mainly south of Krakow, from which people were moving to the core city. And at the same time, these areas were characterised by traditionally high birth rates. In the northern part of the KMA, units were mostly of type $\mathrm{H}$, with dominant agricultural land use, where natural increase did not compensate for the loss caused by migration. Some municipalities adjacent to Krakow represented type B, in which both the natural increase rate and net migration were positive, with the former being the major component of the total population growth. Migration gains were even more important (type C) in the municipality of Zielonki, located near the road to Warsaw, in the proximity of Ojców National Park and, at the same time, situated close $(5 \mathrm{~km})$ to the centre of Krakow. Type C was also represented by Krakow (net migration rate of 3.1\%) and the town of Niepołomice $(4.8 \%)$. By the end of $1980 \mathrm{~s}$, however and before the collapse of communism, migration to urban cores was still more common as a result of previous industrialization.

In 1995, the situation of the major components of total population growth had changed dramatically (Fig. 4b). The number of units representing type A was reduced to 12 , the number of units of type B increased from 4 to 22, and type $\mathrm{C}$ was already represented by 12 municipalities. In addition to the increasing share of net migration in the balance of population, there was also an increase in the typological diversity. While in 1988 there were only four types (A, B, C and $\mathrm{H}$ ), in 1995 , each of the eight types was represented. A

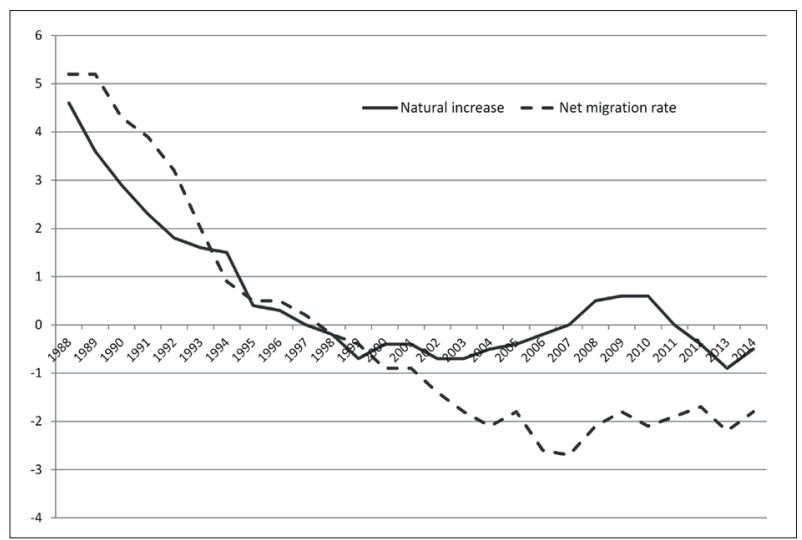

Fig. 3: Main components of population growth in urban areas in Poland in the years 1988-2013 (natural increase and net migration per 1,000 persons) 


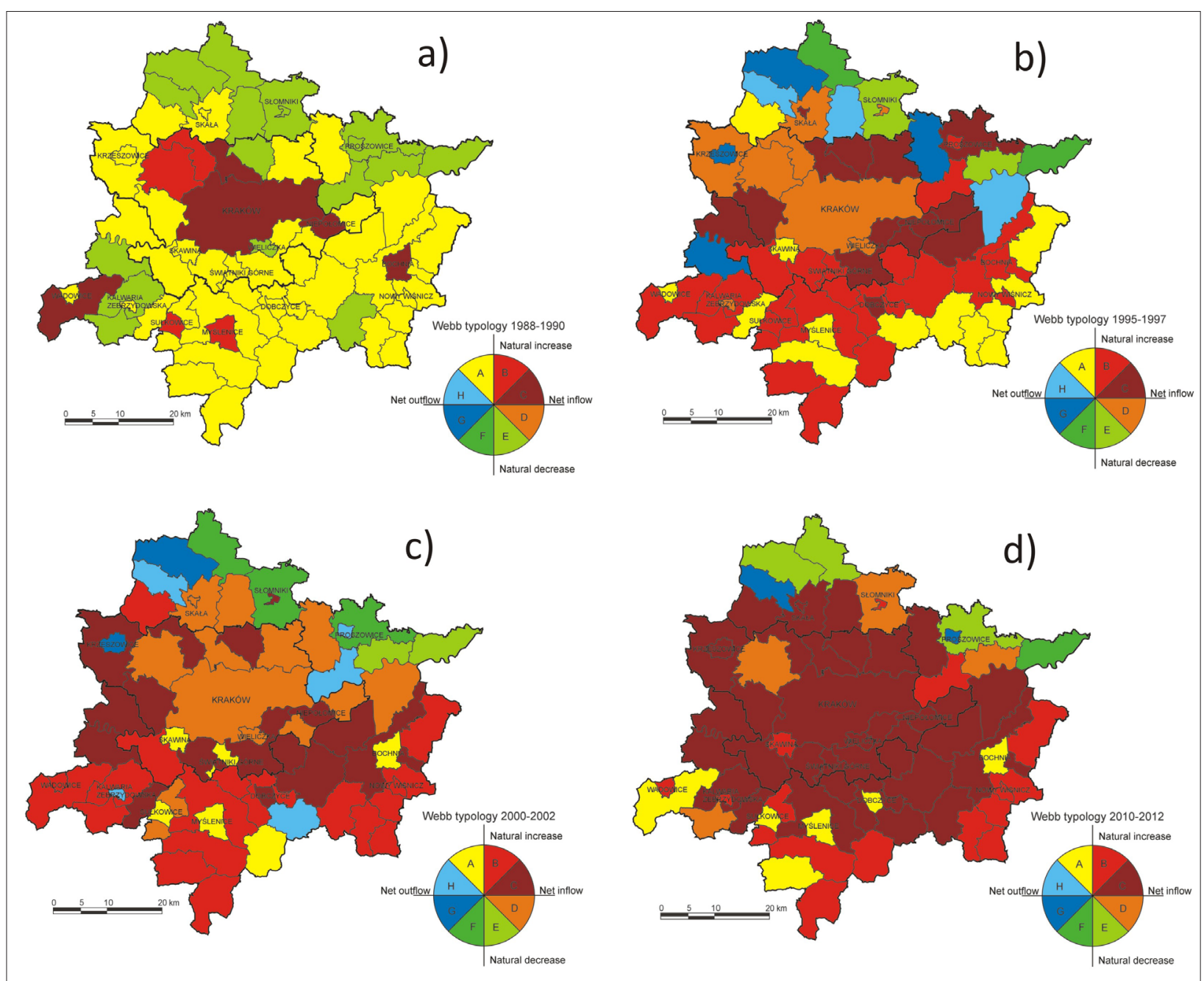

Fig. 4: Static typology of Webb in KMA administrative units - period a) 1988-1990; b) 1995-1997; c) 2000-2002; d) 2010-2012)

distinct suburban area evolved around Krakow, with units of type $\mathrm{C}$ (with higher net migration gains than natural increase) located in the southeast (on the transportation route to the eastern border of the country) and in the north-west. At this point in time, the city of Krakow itself became type $\mathrm{D}$ - despite the positive net migration that was characterised by negative natural population growth, which was typical of most major cities in the 1990s. Municipalities located at the southeast rim of the KMA remained in type A, while the northern part represented types associated with population shrinkage (from $\mathrm{E}$ to $\mathrm{H}$ ).

At the beginning of the twenty-first century, the number of municipalities with net migration higher than natural increase (type C) grew to 18 , and the units of type B and C together accounted for $55 \%$ of all cities and municipalities (Fig. 4c), showing an acceleration of the suburbanisation rate. There was also an increase the number of units of type $\mathrm{D}$, from 8 to 12 . These were mostly the municipalities surrounding Krakow in the north and were characterised by negative balance of natural increase. In the south, however, Krakow was surrounded by units representing type C, which had consistent positive indexes of population growth. In the areas east of Kraków, suburbanisation processes developed much more slowly, which was the result of the operating metallurgical plant and the presence of fertile soils (chernozem and the presence of the so-called "Vegetable Region"). On the other side of the spectrum, type E and F were traditionally represented by municipalities situated on the northern edge of KMA, with high levels of population aging. Gradually, the situation in the housing market improved and the process of suburbanisation became more advanced, not only in the KMA but in all Polish metropolitan areas. The only difference was that Krakow, unlike to most other large cities (with the exception of Warsaw), did not start to lose their population.

In 2012 , there was a further demographic consolidation and growth of the suburban area of KMA. The number of units of type $\mathrm{C}$ increased from 17 to 35 , accounting for more than half of all the surveyed municipalities (Fig. 4d). The second most numerous group of units belonged to type $\mathrm{B}$, covering mainly the eastern and southern margins of the KMA. Unfavourable demographic types (E, F, G) were located on the northern edge of KMA. Joining the European Union and a period of economic prosperity before the onset of financial crisis, led to a boom on the housing market and fuelled the process of suburbanisation in KMA and Poland.

\section{Webb typology (dynamic)}

When comparing the changes in the relationship between the main components of total population growth between the two examined sub-periods (1989-1996 and 2001-2011), it can clearly be seen that at the beginning of the $21^{\text {st }}$ century, the importance of net migration has increased (Fig. 5a, 5c). This situation is similar to most metropolitan areas in Poland, where the communes located in the close neighbourhood of 


\begin{tabular}{|c|c|c|c|c|c|c|c|c|}
\hline \multicolumn{9}{|c|}{ 1988-1995 } \\
\hline Type & $\mathbf{A}$ & B & $\mathrm{C}$ & D & $\mathbf{E}$ & $\mathbf{F}$ & $\mathbf{G}$ & $\mathbf{H}$ \\
\hline $\mathbf{A}$ & 10 & 15 & 8 & 3 & & & 2 & 1 \\
\hline B & 1 & 1 & & 2 & & & & \\
\hline C & & 2 & 2 & 1 & & & & \\
\hline D & & & & & & & & \\
\hline $\mathbf{E}$ & & & & & & & & \\
\hline $\mathbf{F}$ & & & & & & & & \\
\hline G & & & & & & & & \\
\hline $\mathbf{H}$ & 1 & 4 & 2 & 2 & 2 & 2 & 2 & 2 \\
\hline \multicolumn{9}{|c|}{ 1995-2002 } \\
\hline Type & $\mathbf{A}$ & B & $\mathbf{C}$ & D & $\mathbf{E}$ & $\mathbf{F}$ & $\mathbf{G}$ & $\mathbf{H}$ \\
\hline $\mathbf{A}$ & 2 & 8 & 1 & & & & & 1 \\
\hline B & 4 & 10 & 5 & 1 & & & & 2 \\
\hline C & & & 7 & 4 & & 1 & & \\
\hline D & & & 3 & 4 & & & & 1 \\
\hline $\mathbf{E}$ & & & & & 1 & 1 & & \\
\hline $\mathbf{F}$ & & & & & 1 & 1 & & \\
\hline G & & & 1 & 1 & & & 2 & \\
\hline H & & & & 2 & & & & 1 \\
\hline \multicolumn{9}{|c|}{ 2002-2012 } \\
\hline Type & $\mathbf{A}$ & B & C & D & $\mathbf{E}$ & F & $\mathbf{G}$ & $\mathbf{H}$ \\
\hline $\mathbf{A}$ & 3 & 2 & 1 & & & & & \\
\hline B & 2 & 8 & 7 & 1 & & & & \\
\hline C & 1 & 1 & 15 & & & & & \\
\hline D & & 1 & 10 & 1 & & & & \\
\hline $\mathbf{E}$ & & & & 1 & & 1 & & \\
\hline $\mathbf{F}$ & & & & 1 & 2 & & & \\
\hline G & & & 1 & & 1 & & & \\
\hline H & & 2 & 1 & & & & 2 & \\
\hline
\end{tabular}

Tab. 3. The number of changes of Webb types between years under study (the first period in rows).

central cities recorded a significant increase in the number of in-migrants from the core. In the dynamic analysis of the distribution of Webb types, transitions between different years (Tables $3 \mathrm{a}-\mathrm{c}$ ) are presented here.

From 1988-1995, the most common transition between types was a combination of A and B (which was represented by 15 units). In 10 cases, the unit retained type A, while in eight (8) units there was a transition from type A to C. In the period 1995-2002, the changes in the distribution of types were more stable. The most recurrent transition regarding Webb types was the combination of B-B (10 records), then A-B (8 records) and C-C (7 times). From 2002-2012, 15 municipalities retained type $\mathrm{C}$, and the second most common transition was the combination of type $\mathrm{D}$ to type $\mathrm{C}$ (which was from the type with negative population increase to the type where both components are positive): 10 cases. In general, most transformations of types were connected with the growing importance of net migration which confirmed the process of suburbanisation, a pattern characteristic in Poland for all large cities as well as middle-sized towns.

The surveyed cities and municipalities of KMA, in all three sub-periods (1988-1995, 1995-2002, and 2002-2012) were dominated by the main type I (permanent populating): in
1988-1995 it covered 45 spatial units (69 per cent, located usually in the central and southern zone of the KMA); in 1995-2002, 49 units (3/4 of the total number of cities and municipalities); and in the years 2002-2012, 53 units (82 per cent). In other words, the number of KMA units with an increase in population grew between the examined time periods - despite the general trend of a decreasing population growth. Only four municipalities (located on the northern edge of the KMA) in all periods had reported 'permanent depopulating' (type IV).

These four main types were compared with the four subtypes. According to this classification, in the period 1989-1996, there were 12 combinations of which the most numerous was sub-type Ib, indicating the increasing role of migration in the continuation of the process of populating, which is characteristic of the phase of suburbanisation (Fig. 5a). This group of municipalities included Krakow and the first ring, and in the south the second and even third ring of surrounding units. Another large group of units was marked with Io, that is, units with an increase in population and where the relationship between the components of this growth remained unchanged. The first period of socioeconomic transition in Polish urban areas was indicated by a decreasing role of natural increase in population change. In the period 1996-2001, in the KMA, there was a further increase in the stabilisation of the units with regard to the dynamics of Webb types, since the most numerous subtype combination was Io (23 units), dominated by the type B (10 units). A common sub-type was Ib (19 units), associated with an increasing role for net migration (Fig. 5b).

Units representing sub-types of Io and Ib together accounted for almost two-thirds of all surveyed cities and municipalities. Units located on the northern edge of KMA were also stable, but remained within the main type of permanent depopulation (Webb types E, F, G and H).

In the last investigated period, 2001-2011, the sub-types were characterised by a higher spatial concentration (Fig. 5c). As many as 53 units ( 82 per cent of the total) represented only three sub-types. The most numerous sub-type was the stabilised Io (27 units), the second common was sub-type Ia, with an increase in natural population growth in relation to net migration. The third most numerous was the sub-type $\mathrm{Ib}$, in which the dominant component of the total population growth changed from natural increase to migratory growth. These units were located in the southern part of KMA.

Thus, in the last period under study, covering the time of joining the EU, reflected the trends in all districts in Poland, where fertility recorded a slight increase. It was associated with completed postponement of births to later ages of mother, after the first decade of socio-economic transition, economic improvements connected with EU accession, as well as introducing some pro-natalist policy measures (baby bonuses, extending parental leaves, etc.). At the local level, the rise in natural increase can be the result of selective migration as the decision to migrate can depend on people's plans to start or expand their family; the suburban environment may encourage the decision to have more children (Vobecka and Piguet, 2012; Kulu and Boyle, 2009).

After joining the EU, natural increases accounted for 38 percent of the population change in the KMA in 2008, while before 2004 net migration often surpassed total population growth and compensated for natural losses. The main direction of migration was from Krakow to its hinterland, which contributed to the ongoing suburbanisation. 


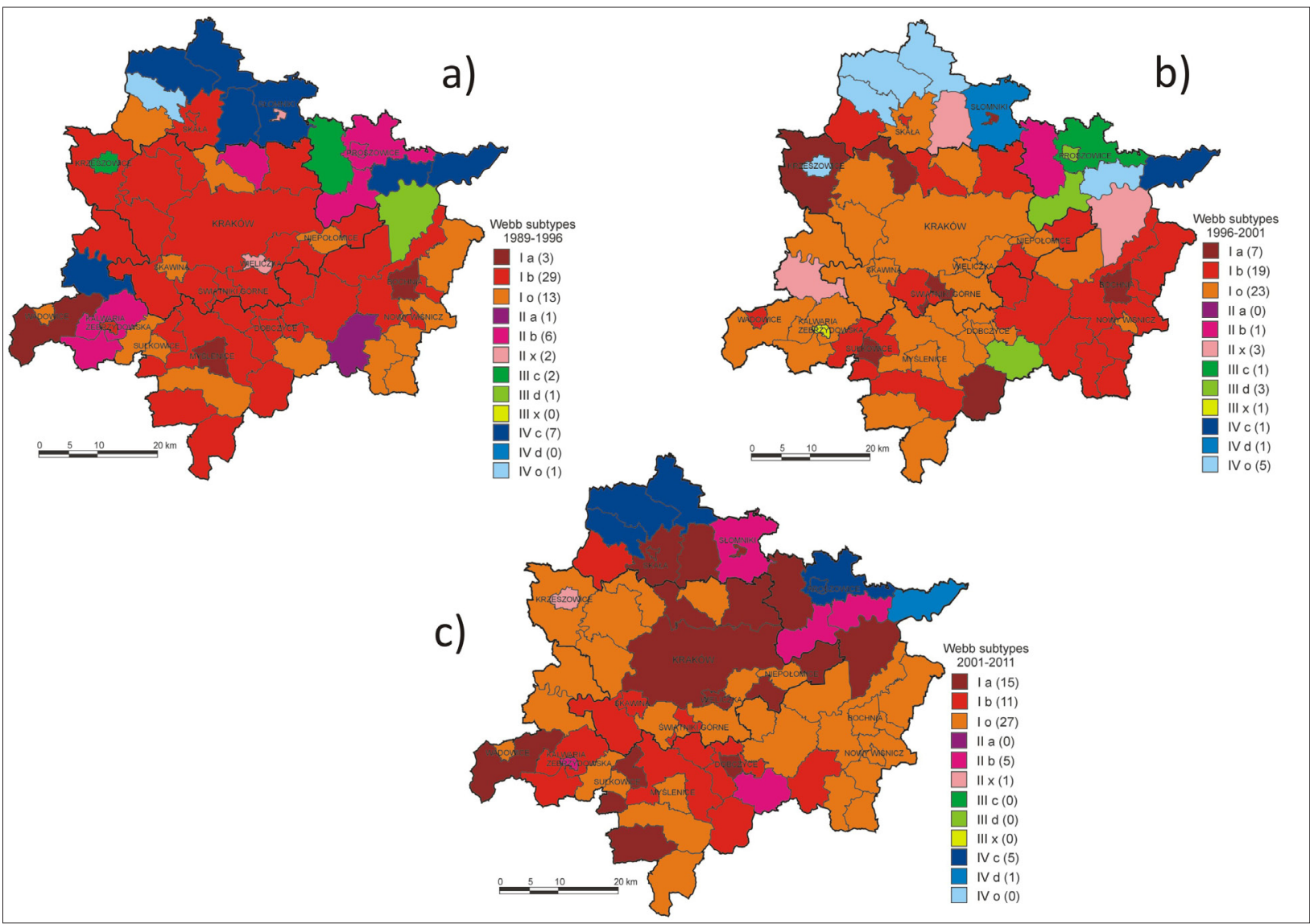

Fig. 5: Dynamic typology of Webb in KMA administrative units

In the immediate fringes around the city, from 1988-2013, only 25 percent of migration flows came from outside the Krakow Metropolitan Area, while in the "to commuting zone" it was 36 percent (Kurek et al., 2014). In other large urban areas in Poland (within their administrative borders), the situation was slightly different as they began to lose their population after 2000 and this pattern persisted with negative migration balance, contributing mostly to their population decline. Positive natural increase in recent years did not compensate for negative population growth. The share of population living in urban areas in Poland decreased from 62 to 60 per cent in the years 1988-2013, and most of this decrease has been fuelled by the growth of suburban areas.

\section{Conclusions}

Residential suburbanisation processes taking place in the Krakow Metropolitan Area are diverse in terms of population dynamics and in terms of the relationships between the main components of total population growth, both static and dynamic. We studied the long-term spatial patterns of population dynamics across suburban contexts and our results showed reversed trends since the 1990s, with a growing importance of residential migration and, in recent years, gains in natural increase. These results are similar to patterns observed in research by Vobecka and Piguet (2012), where a reversal of spatial population dynamics over the last 20 years has had a modest but undeniable impact on fertility levels. This is also in line with recent research which revealed that residential mobility is an important factor influencing the level of fertility in suburban areas (Boyle, 2003; Kulu, 2005; Mulder, 2006; Kulu and Vikata, 2007; Kulu and Boyle, 2009; Kulu et al., 2009). The decision to change the place of residence often takes into account enlargement plans or the start of a family. On the other hand, a more comfortable and larger apartment in a friendly environment can promote an increase in fertility levels (suburban contextual effect, Kulu et al., 2009). According to survey research made by Kurek et al. (2014), more suburban migrants intended to have children than suburban non-migrants.

Spatial differences within metropolitan areas, however, still exist. Municipalities located on the northern edge of the KMA with mainly agricultural land use, have lagged behind, showing a decrease in population numbers. While in the first time period (1988) most municipalities belonged to type $\mathrm{H}$ in the Webb system (where birth rate does not compensate for the loss of population due to migration), by 2012 there was a shift to type $\mathrm{E}$, where net migration was positive but it did not balance the natural loss of population. In the 1990 s and 2000 s, most of these municipalities recorded negative values of both components of population growth. In the dynamic Webb typology, they experienced permanent depopulation with a decreasing role of birth rates.

The zone of cities and municipalities in the immediate vicinity of Krakow was characterised by a significant increase in population (especially along main transportation routes), except for areas located east of Nowa Huta, which was due to intensive agricultural land use and in proximity to the steelworks. In the Webb typology, these units were initially marked as type A. But in the first analysed subperiod (1988-1995) there was a clear shift to type C, with an increased role of net migration and then a stable trend of permanent populating with a dominant component of migration. This zone is an area of the most intense process of suburbanisation and an associated influx of migration, mainly from Krakow. The trend was revealed 
in the first of the analysed time periods and strengthened in the next studied periods, reaching its maximum values in the years 2002-2012. The economic boom after joining the EU, the improvement of the economic situation and the ease in obtaining housing loans, "pushed" the highest wave of migrants to suburban zones. In time, there were slight increases in family sizes, as families sought new more spacious and more comfortable suburban homes.

The southern zone of KMA, traditionally characterised by high birth rates, initially consisted of units classified as type A, and later to type B, according to Webb. Municipalities in this area, belonging to the main type - permanent populating - were usually characterised by increasing levels of migration, although in the last sub-period more and more units showed a change from dominant net migration to dominant natural increase.

It should also be emphasized that the KMA is far more heterogeneous in terms of settlement and, beyond the dominance of agricultural land, an important role in the concentration of population is also played by small towns (as in Myślenice, Dobczyce, Wadowice, Bochnia). These centers today are becoming increasingly significant industrial centers on the one hand, characterised by the transfer of industrial plants from Krakow, and on the other hand, actively attracting new greenfield investments. These towns also produce their own zone of suburbanisation, with local systems of migration characterised on the one hand by the outflow of population from cities to surrounding rural areas with little flow in the opposite direction, and on the other hand these satellite towns are often attractive to in-migrants moving from Krakow (Kurek, Gałka, Wójtowicz, 2014).

The static and dynamic Webb typology is a helpful framework or scheme to analyse the diversity of population dynamics and its components. Using the example of the KMA, this typology demonstrated the spreading of residential suburbanisation by the changing relationship between migration and fertility in the populating of areas located outside of the core city of Krakow.

These results allow us to assess the scale of changes of particular components of population change in the studied time sections, which could be valuable information for local authorities in planning further development of individual municipalities. The lack of coordinated management of metropolitan areas in Poland is responsible in many ways for urban sprawl (Lisowski et al., 2013). The fragmentation of administrative units and non-existent official statistics for delimiting suburban areas defined on the basis of commuting data, makes effective urban growth management difficult. Nonetheless, in broader spatial terms, these results may be useful in the planning of regional development, especially of the road network and public transport as municipalities developing in the light of the typology. Spatial units defined by the Webb scheme mainly grow as a result of positive net migration and the accompanying greater spatial mobility of their inhabitants. Especially for their new residents, the commute-to-work or -school mostly relates to the core of the metropolitan region. Specifying specific types of demographic developments among municipalities within the KMA also allows us to forecast the dominant social behaviors of the population, in terms of commuting to work or school, and to the use of different types of services and the creation of functional and spatial ties between administrative units. This information might therefore be particularly useful in planning further socio-economic development of the Krakow metropolitan region.

\section{Acknowledgement}

This study was funded by the National Science Centre, awarded by decision number: DEC-2012/05/B/HS4/04200: "Transformation of selected social-demographic structures in Krakow Metropolitan Area”.

\section{References:}

BEIM, M. (2010): Modelowanie procesu suburbanizacji w aglomeracji poznańskiej. Poznań, Wyd. Bogucki.

VAN DER BERG, L., DREWETT, R., KLAASEN, L. H., ROSSI, A., VIJVERBERG, C. H. T. [eds.] (1982): Urban Europe: A Study of Growth and Decline. Oxford, Pergamon Press.

BONGAARTS, J. (2002): The end of the fertility transition in the developed world. Population and Development Review, 28(3): 419-443. doi: http://dx.doi.org/10.1111/ j.1728-4457.2002.00419.x.

BOYLE, P. (2003): Population geography: does geography matter in fertility research? Progress in Human Geography, 27(5): 615-626. doi: http://dx.doi. org/10.1191/0309132503ph452pr.

BOYLE， P. J., GRAHAM, E., FENG, Z. (2008): Contextualising demography: The significance of local clusters of fertility in Scotland. Rostock, Max Planck Institute for Demographic Research (MPIDR working paper, WP-2008-036). Available at: http://www.demogr. mpg.de/papers/working/wp-2007-036.pdf

DŁUGOSZ, Z. (2001): Próba dynamicznej typologii ruchu ludności w świetle klasyfikacji Webba na przykładzie województwa małopolskiego. In: Kortus, B., [ed.]: Człowiek i Przestrzeń (pp. 61-70). Kraków, IGiGP UJ.

ENYEDI, G. (1992): Urbanisation in East Central Europe. Social Processes and Societal Responses in the State Socialist Systems. Urban Studies, 29(6): 869-880. doi: http://dx.doi.org/10.1080/00420989220080851.

ENYEDI, G. (1996): Urbanization under socialism. In: Andrusz, G., Harloe M., Szelenyi I., [eds.]: Cities after socialism. Urban and regional change and conflict in post-socialist societies (pp. 100-118). Oxford, Blackwell Publishers.

ENYEDI, G. (1998): Transformation in Central European Postsocialist Cities. Pécs, Centre for Regional Studies of Hungarian Academy of Sciences, Discussion Papers, 21: 5-47.

GAŁKA，J., WARYCH-JURAS, A. (2011): Regionalne uwarunkowania suburbanizacji w Polsce. In: Słodczyk, J. [ed.]: Procesy suburbanizacji w wybranych miastach Polski (pp. 147-158). Opole, Wyd. Uniwersytetu Opolskiego.

GENTILE, M., TAMMARU, T., VAN KEMPEN, R. (2012): Heteropolitanization: social and Spatial change in Central and Eastern European cities. Cities, 29(5): 291299. doi: http://dx.doi.org/10.1016/j.cities.2012.05.005.

GRZESZCZAK, J. (1996): Tendencje kontrurbanizacyjne w krajach Europy Zachodniej. Prace Geograficzne, IGiPZ PAN, 167. Wrocław, Wyd. Continuo.

HAASE, A., KABISCH, S., STEINFÜHRER, A., BOUZAROVSKI, S., HALL, R., OGDEN, P. (2010): Emergent spaces of reurbanisation: exploring the demographic dimension of inner-city residential change in a European setting. Population, Space and Place, 16(5): 443-463. doi: http://dx.doi.org/10.1002/psp.603. 
HIRT, S. (2007): Suburbanising Sofia: Characteristics of post-socialist peri-urban change. Urban Geography, 28(8): 755-780. doi: http://dx.doi.org/10.2747/02723638.28.8.755.

JAKÓBCZYK-GRYSZKIEWICZ， J. (1998): Przeobrażenia stref podmiejskich dużych miast. Studium porównawcze strefy podmiejskiej Warszawy, Łodzi i Krakowa. Łódź, Wyd. Uniwersytetu Łódzkiego.

JAKÓBCZYK-GRYSZKIEWICZ, J. (2011): Regiony miejskie w Polsce. Dwadzieścia lat transformacji. Łódź, Wyd. Uniwersytetu Łódzkiego.

KABISCH, N., HAASE, D., HAASE, A. (2012): Urban population development in Europe 1991-2008: The examples of Poland and UK. International Journal of Urban and Regional Research, 36(6): 1326-1348. doi: http://dx.doi.org/10.1111/j.1468-2427.2012.01114.x.

KAJDANEK, K. (2011): Pomiędzy miastem a wsią. Suburbanizacja na przykładzie osiedli podmiejskich Wrocławia. Kraków, Nomos.

KAJDANEK, K. (2012): Suburbanizacja po polsku. Kraków, Nomos.

KLASSEEN, L. H., MOLLE, W. T., PAELINCK J. H. P. (1981): The dynamics of urban development: proceedings of an international conference held on the occasion of the $50^{\text {th }}$ anniversary of the Netherlands Economic Institute, in Rotterdam, September 4, 1979. New York, St. Martin's Press.

KULU, H. (2005): Migration and Fertility: Competing Hypotheses Re-examined, European Journal of Population, 21(1): 51-87. doi: http://dx.doi.org/10.1007/ s10680-005-3581-8.

KULU, H., VIKAT, A. (2007): Fertility differences by housing type: The effect of housing conditions or of selective moves? Demographic Research, 17(26): 775-802. doi: http://dx.doi.org/10.4054/DemRes.2007.17.26.

KULU, H., BOYLE, P.J. (2009): High Fertility in City Suburbs: Compositional or Contextual Effects? European Journal of Population, 25(2): 157-174. doi: http://dx.doi. org/10.1007/s10680-008-9163-9.

KULU, H., BOYLE, P. J., ANDERSSON, G. (2009): High suburban fertility: Evidence from four Northern European countries. Demographic Research, 21(31): 915-944. doi: http://dx.doi.org/10.4054/ DemRes.2009.21.31.

KULU, H., WASHBROOK E. (2014): Residential Context, Migration and Fertility in a Modern Urban Society. Advances in Life Course Research, 21: 168-182. doi: http://dx.doi.org/10.1016/j.alcr.2014.01.001.

KUREK, S., GAŁKA, J., WÓJTOWICZ, M. (2014): Wpływ suburbanizacji na przemiany wybranych struktur demograficznych i powiązań funkcjonalnoprzestrzennych w Krakowskim Obszarze Metropolitalnym. Kraków: Wydawnictwo Instytutu Geografii Uniwersytetu Pedagogicznego w Krakowie.

LADANYI J., SZELENYI, I. (1998): Class, ethnicity and urban restructuring in postcommunist Hungary. In: Enyedi, G. [ed.]: Social change and urban restructuring in Central Europe (pp. 67-86). Budapest, Akademiai Kiado.

LEETMAA, K., TAMMARU, T. (2007): Suburbanization in countries in transition: Destinations of suburbanizes in the Tallinn Metropolitan Area. Geografiska Annaler B, 98(2): 127-146. doi: http://dx.doi.org/10.1111/j.14680467.2007.00244.x.

LEETMAA, K., TAMMARU, T., ANNISTE, K. (2009): From priority-led to market-led suburbanization in a postcommunist metropolis. Tijdschrift voor economische en sociale geografie, 100(4): 436-453. doi: http://dx.doi. org/10.1111/j.1467-9663.2009.00551.x.

LESTHAEGHE, R. (2010): The Unfolding Story of the Second Demographic Transition. Population and Development Review, 36(2): 211-251. doi: http://dx.doi. org/10.1111/j.1728-4457.2010.00328.x.

LESTHAEGHE, R., MEEKERS, D. (1986): Value Changes and the Dimensions of Familism in the European Community. European Journal of Population, 2(3): 225268. doi: http://dx.doi.org/10.1007/BF01796593.

LISOWSKI, A. (2010): Suburbanizacja w Obszarze Metropolitalnym Warszawy. In: Ciok, S., Migoń, P., [eds.]: Przekształcenia struktur regionalnych. Aspekty społeczne, ekonomiczne i przyrodnicze (pp. 93-108). Wrocław, Instytut Geografii i Rozwoju Regionalnego, Uniwersytet Wrocławski.

LISOWSKI A., MANTEY D., WILK W. (2014): Lessons from Warsaw. The Lack of Coordinated Planning and Its Impacts on Urban Sprawl. In: Stanilov, K., Sýkora, L. [eds.]: Confronting Suburbanization. Urban Decentralization in Postsocialist Central and Eastern Europe (pp. 225-255). Chichester-Oxford, Wiley Blackwell.

MARCIŃCZAK, S. (2012): The evolution of spatial patterns of residential segregation in Central European Cities: The Łódź Functional Urban Region from mature socialism to mature post-socialism. Cities, 29(5): 300-309. doi: http:// dx.doi.org/10.1016/j.cities.2011.08.008.

MULDER, C. H. (2006): Population and housing: a two-sided relationship. Demographic Research, 15(13): 401-412. doi: http://dx.doi.org/10.4054/DemRes.2006.15.13.

MURRAY, P., SZELENYI, I. (1984): The city in the transition to socialism. International Journal of Urban and Regional Research, 8(1): 90-107. doi: http://dx.doi. org/10.1111/j.1468-2427.1984.tb00415.x.

OUŘEDNÍČEK, M. (2007): Differential suburban development in the Prague Urban Region. Geografiska Annaler B, 89(2): 111-126. doi: http://dx.doi.org/10.1111/ j.1468-0467.2007.00243.x.

PARYSEK, J., WDOWICKA, M. (2002): Polish socio-economic transformation: winners and losers at the local level. European Urban and Regional Studies, 9(1): 73-80. doi: http://dx.doi.org/10.1177/096977640200900108.

RAE, A. (2013): English urban policy and the return to the city: A decade of growth, 2001-2011. Cities, 32: 94-101. doi: http://dx.doi.org/10.1016/j.cities.2013.03.012

RAŹNIAK, P., WINIARCZYK-RAŹNIAK, A. (2013): Spatial distribution and differences in migration patterns and revenues of gminas in the Kraków Metropolitan Area. Bulletin of Geography. Socio-economic Series, 19(19): 7386. doi: http://dx.doi.org/10.2478/bog-2013-0005.

REBERNIK, D. (2005): Urbanization trends and processes of population change in the Lubljana Urban Region in 1990s. Geographia Polonica, 78(1): 67-78. 
RÉRAT, P. (2012): The new demographic growth of cities: The case of reurbanisation in Switzerland. Urban Studies, 49(5): 1107-1125. doi: http://dx.doi. org/10.1177/0042098011408935.

SŁODCZYK, J. (2001): Przestrzeń miasta i jej przeobrażenia. Studia i Monografie, Opole, Wyd. Uniwersytetu Opolskiego.

ŠPACKOVÁ, P., OUŘEDNÍČEK, M. (2012): Spinning the web: new social contacts of Prague's suburbanites. Cities, 29(5): 341-349. doi: http://dx.doi.org/10.1016/j. cities.2011.09.002

STANILOV, K. (2007): Housing trends in central and eastern European cities during and after the period of transition. In: Stanilov, K. [ed.]: The Post-socialist City: Urban Form and Space Transformations in Central and Eastern Europe after Socialism (pp. 173-190). Dordrecht, Springer.

STANILOV K., SÝKORA L. [eds.] (2014): Confronting suburbanization. Urban decentralization in postsocialist Central and Eastern Europe. Chichester-Oxford, Wiley Blackwell.

STEINFÜHRER, A., HAASE, A. (2007): Demographic Change as a Future Challenge for Cities in East Central Europe. Geografiska Annaler B, 89(2): 183-195. doi: http://dx.doi.org/10.1111/j.1468-0467.2007.00247.x.

STEINFÜHRER, A., BIERZYŃSKI, A., GROßMANN, K., HAASE, A., KABISCH S., KLUSÁCEK P. (2010): Population Decline in Polish and Czech Cities during Post-socialism? Looking Behind the Official Statistics. Urban Studies, 47(11): 2325-2346. doi: http://dx.doi. org/10.1177/0042098009360224.

SÝKORA, L. (1999): Changes in the internal spatial structure of post-communist Prague. GeoJournal, 49(1): 79-89. doi: http://dx.doi.org/10.1023/A:1007076000411.

SZELENYI I. (1996): Cities under socialism - and after. In: Andrusz G., Harloe M., Szelenyi I. [eds.]: Cities after socialism. Urban and regional change and conflict in post-socialist societies (pp. 286-317). Oxford, Blackwell Publishers.

SZYMAŃSKA, D., MATCZAK, A. (2002): Urbanization in Poland: tendencies and transformation. European Urban and Regional Studies, 9(1): 39-46. doi: http://dx.doi. org/10.1177/096977640200900104.

ŚLESZYŃSKI, P. (2006): Demograficzny wymiar procesów suburbanizacji w Polsce po 1989 roku. In: Kozłowski, S. [ed.]: Żywiołowe rozprzestrzenianie się miast. Narastający problem aglomeracji miejskich w Polsce, Studia nad zrównoważonym rozwojem, t. 2, (pp. 105123). Białystok-Lublin-Warszawa, Katedra Ochrony Środowiska KUL, Komitet Człowiek i Środowisko przy Prezydium PAN.

ŚLESZYŃSKI, P. (2011): Oszacowanie rzeczywistej liczby ludności gmin województwa mazowieckiego $\mathrm{z}$ wykorzystaniem danych ZUS. Studia Demograficzne, 2(160): 35-58.
TAMMARU, T. (2001): Suburban Growth and Suburbanization under Central Planning: The Case of Soviet Estonia. Urban Studies, 38(8): 1341-1357. doi: http://dx.doi.org/10.1080/00420980120061061.

TAMMARU, T. (2005): Suburbanization, employment change, and commuting in the Tallinn metropolitan area. Environment and Planning A, 37(9): 1669-1687. http://dx.doi.org/10.1068/a37118.

VAN DE KAA, D. (1987): Europe's second demographic transition. Population Bulletin, 42: 1-57.

VOBECKÁ, J., PIGUET, V. (2012): Fertility, Natural Growth, and Migration in the Czech Republic: an UrbanSuburban-Rural Gradient Analysis of Long-Term Trends and Recent Reversals. Population, Space and Place, 18(3): 225-240. doi: http://dx.doi.org/10.1002/psp.698.

WARYCH-JURAS, A., GAŁKA J. (2011): Starzenie się ludności w polskich obszarach metropolitalnych. In: Soja, M., Zborowski A. [eds.]: Człowiek w przestrzeni zurbanizowanej (pp. 99-110). Kraków, IGiGP UJ.

WEBB, J.W. (1963): The Natural and Migrational Components of Population Changes in England and Wales, 1921-1931, Economic Geography, 39(2): 130-148.

WĘCŁAWOWICZ， G., BAŃSKI， J., DEGÓRSKI, M., KOMORNICKI, T., KORCELLI, P., ŚLESZYŃSKI,P.(2006): Przestrzenne zagospodarowanie Polski na początku XXI wieku. Monografie IGiPZ PAN, 6. Warszawa, PAN IGiPZ.

WIĘCŁAW-MICHNIEWSKA, J. (2011): Suburbanizacja w Krakowskim Obszarze Metropolitalnym. In: JakóbczykGryszkiewicz, J. [ed.]: Regiony miejskie w Polsce. Dwadzieścia lat transformacji (pp. 73-88). Łódź, Wydawnictwo Uniwersytetu Łódzkiego.

WIŚNIEWSKI, R. (2014): The spatial and nationality aspects of depopulation in the European part of the Russian Federation. Geographia Polonica, 87(1): 47-59, doi: http://dx.doi.org/10.7163/GPol.2014.3.

ZBOROWSKI, A. (2005): Przemiany struktury społecznoprzestrzennej regionu miejskiego $\mathrm{w}$ okresie realnego socjalizmu transformacji ustrojowej (na przykładzie Krakowa). Kraków, IGIGP UJ.

ZBOROWSKI A., CHABERKO T., GRAD N., KRETOWICZ P. (2010): Delimitacja Krakowskiego Obszaru Metropolitalnego. In: Domański, B. [ed.]: Małopolskie miasta - funkcje, potencjał i trendy rozwojowe (pp. 517-543). Kraków, Małopolskie Studia Regionalne, Małopolskie Obserwatorium Polityki Rozwoju.

ZBOROWSKI A., CHABERKO T., KRETOWICZ P. (2011): Procesy suburbanizacji rezydencjonalnej $\mathrm{w}$ regionie miejskim Krakowa: przemiany społeczno-przestrzenne. In: Jakóbczyk-Gryszkiewicz, J. [ed.]: Regiony miejskie w Polsce. Dwadzieścia lat transformacji (pp. 49-72). Łódź, Wydawnictwo Uniwersytetu Łódzkiego.

ZBOROWSKI, A., RAŹNIAK, P. (2013): Suburbanizacja rezydencjonalna w Polsce - ujęcia badawcze i ocena procesu. Studia Miejskie, 9: 37-50.

Initial submission 30 January 2015, final acceptance 30 November 2015

Please cite this article as:

KUREK, S., WÓJTOWICZ, M., GAŁKA, J. (2015): The changing role of migration and natural increase in suburban population growth: The case of a non-capital post-socialist city (the Krakow Metropolitan Area, Poland). Moravian Geographical Reports, 23(4): 59-70. DOI: 10.1515/mgr-2015-0025. 